\title{
THE MEDIAL MORAINES OF THE LOWER GLAGIER DE TSIDJIORE NOUVE, VALAIS, SWITZERLAND
}

\author{
By R. J. Small and M. J. Clark \\ (Department of Geography, University of Southampton, Southampton, England)
}

\begin{abstract}
The two medial moraines of the Glacier de Tsidjiore Nouve are nourished by rock debris revealed at the surface by progressive ablation down-glacier. The sources of the moraine appear to be rock outcrops marginal to or above the Pigne d'Arolla ice fall, much of the detritus entering the glacier via crevasses either at the summit or the base of the ice fall. The role of differential ablation in the emergence of the moraines as relief features is illuminated by measurements made in the late summers of 1971 and 1972 . The eventual decline of the moraines down-glacier is related to factors of reducing debris supply, lateral sliding and accelerated ablation due to attenuation of the detrital cover to a mean thickness of $\mathrm{I} \mathrm{cm}$ or less. A model of moraine development, different in several respects from that proposed by Loomis (1970) for the Kaskawulsh Glacier, Alaska, is outlined.

RÉsumé. Les moraines medianes de la partie inferieure du glacier de Tsidjiore Nouve dans le Valais, Suisse. Les deux moraines médianes du glacier de Tsidjiore Nouve sont nourries par des débris de roc qui apparaissent à la surface en raison de l'ablation progressive au bas du glacier. Les sources de la moraine semblent être un affleurement rocheux, marginal à la cascade de séracs de la Pigne d'Arolla, beaucoup de détritus pénétrant dans le glacier par les crevasses formées à la base de la cascade. Le rôle de l'ablation différentielle dans l'émergence des moraines comme des reliefs, est illustré par les mesures faites en fin d'été 1971 et 1972. L'éventuel abaissement des moraines au bas du glacier est en relation avec les facteurs de réduction de l'approvisionnement en débris, avec le glissement latéral, et avec l'accélération de l'ablation en raison de l'amincissement de la couche de débris jusqu'à une épaisseur moyenne de $1 \mathrm{~cm}$ ou moins. On évoque un modèle de développement de moraine, différent à plusieurs égards de celui proposé par Loomis (1970) pour
le Kaskawulsh Glacier, Alaska.

Zusammenfassung. Die Mittelmoränen des Unteren Tsidjiore-Nouve-Gletschers, Wallis, Schweiz. Die beiden Mittelmoränen des Tsidjiore-Nouve-Gletschers werden von Felsschutt ernährt, der durch die gletscherabwärts zunehmende Ablation an die Eisoberfläche gelangt. Die Quellen der Moräne scheinen Flesvorsprünge am Rande des Pigne d'Arolla-Eisfalls zu sein. Der grösste Teil des Gerölls gelangt durch Spalten, die sich am Untergrund des Eisfalls bilden, in den Gletscher. Durch Messungen in den Spätsommern 197 I und 1972 wurde die Bedeutung wechselnder Ablation für das Hervortreten der Moränen als Relieferscheinungen geklärt. Der gelegentliche Verfall der Moränen gletscherabwärts hängt von folgenden Faktoren ab: Abnahme der Geröllzufuhr, seitliches Gleiten und beschleunigte Ablation infolge von Verminderung der Schuttbedeckung auf eine Durchschnittsdicke von $1 \mathrm{~cm}$ oder noch weniger. Ein Modell der Moränenentwicklung wird vorgelegt, das sich in mehreren Beziehungen von dem von Loomis (197o) für den Kaskawulsh
Glacier vorgeschlagenen unterscheidet.
\end{abstract}

THE lower part of the Glacier de Tsidjiore Nouve extends approximately $2 \mathrm{~km}$ northeastwards from the base of the ice fall flanking the northern face of the Pigne d'Arolla $(3796 \mathrm{~m})$, at the head of the Arolla branch of the Val d'Hérens, Valais, Switzerland (Fig. I). The glacier is notable for its considerable burden of supraglacial moraine, largely composed of blocks and finer fragments of light grey gneiss of the Arolla Series of the Dent Blanche Nappe and highly fractured darker schists of the Schistes Lustrés Series. This material forms two well-defined medial moraines, each approximately $\mathrm{I} \mathrm{km}$ in length, which at their downglacier ends spread to merge with marginal morainic debris. Of the two moraines that to the south (right) is markedly broader and higher (reaching a width of ro $\mathrm{m}$ and a maximum elevation of $22.25 \mathrm{~m}$ above nearby bare ice, compared with corresponding figures of $59 \mathrm{~m}$ and $6 \mathrm{~m}$ for the northern moraine), and will accordingly be referred to throughout this paper as the main moraine; that to the north (left) is termed the subsidiary moraine.

\section{A. THE Form of THE MEdial MORAINES}

Despite differences of scale, the two moraines have certain features in common:

(I) From their positions and orientations both appear to be nourished by rock outcrops either above or to each side of the Pigne d'Arolla ice fall; the uncertainty over the latter point is due simply to the absence of observable continuity of debris between source and moraine. 


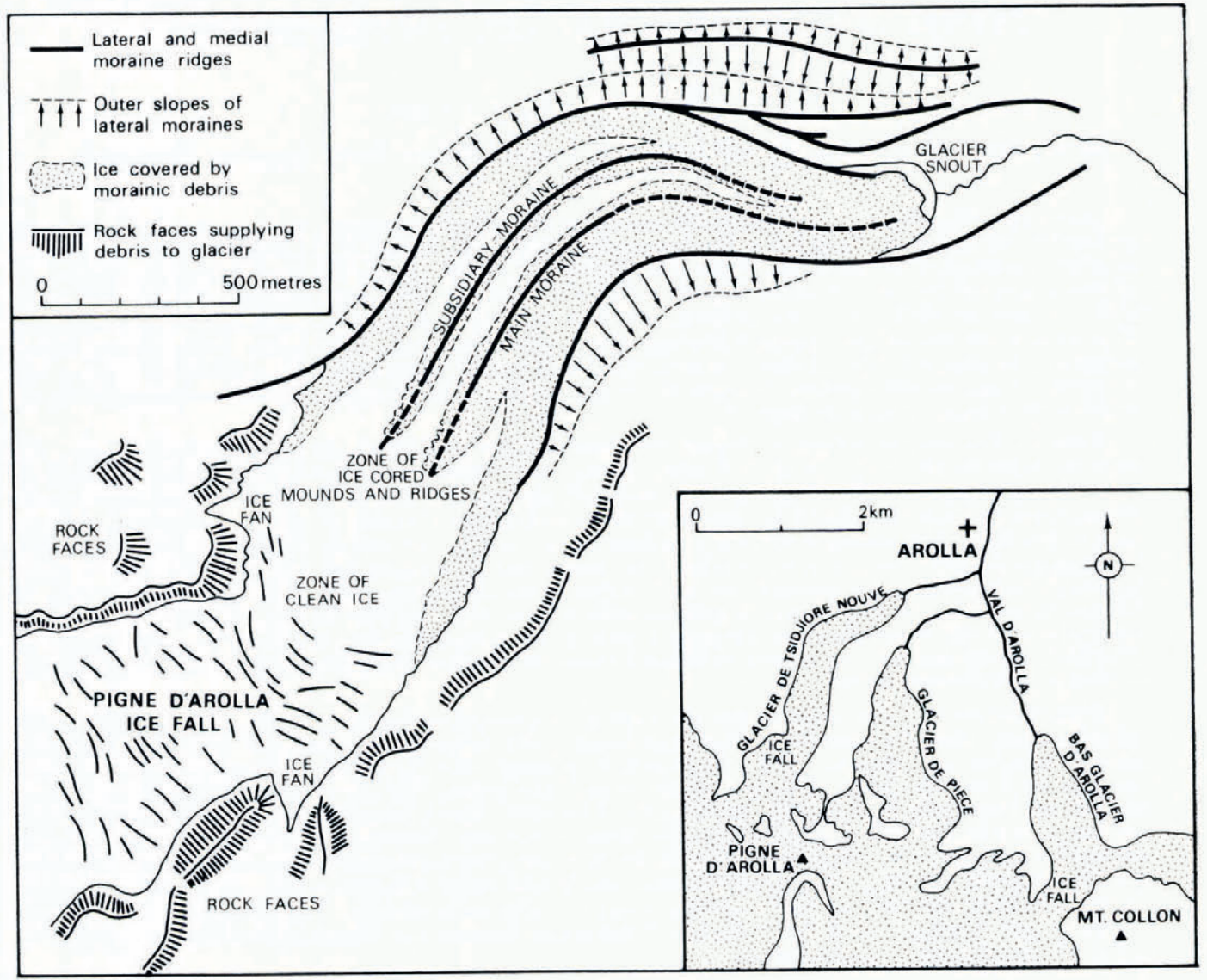

Fig. I. Location and main features of the Glacier de Tsidjiore Nouve.

The uppermost part of the lower Glacier de Tsidjiore Nouve is, in fact, comparatively free of surface rocks, and the medial moraines only begin to take shape over $400 \mathrm{~m}$ down-glacier from the base of the ice fall. The most likely explanation of this discontinuity is that frostshattered material falls directly into crevasses and emerges at the surface as a result of prolonged ablation farther down the glacier (Embleton and King, 1968, p. 345).

(2) The two moraines in their upper parts take the form of discontinuous mounds of surface debris, which gradually merge to give continuous ridges (Fig. 2). The main moraine in particular consists at first of a series of debris-covered ice mounds, ice cones and ice ridges, with the major axes of the latter orientated across the glacier. Aerial photographs show that the cones and ridges are closely related to the dark ice bands of the ogives that are well developed on the lower Glacier de Tsidjiore Nouve (King and Lewis, I96r).

(3) The main and subsidiary moraines are, as relief features, composed overwhelmingly of glacier ice, which is merely overlain by a veneer of fine gritty and stony debris (usually about $5^{-10} \mathrm{~cm}$ in thickness), together with large numbers of angular gneiss and schist fragments up to and exceeding $\mathrm{I} \mathrm{m}$ in maximum dimension.

(4) Both moraines grow in height, relative to adjacent bare ice, in a down-glacier direction, and reach points of maximum elevation beyond which they undergo decline. In the case of the subsidiary moraine this decline is gentle over a distance of several hundreds of metres, but 
the main moraine, after fluctuating in height below the point of maximum elevation, loses height more rapidly (Fig. 2). A notable feature is that the continuity of the debris cover of the two moraines becomes less perfect down-glacier, with the gritty layer being attenuated and patches of bare or nearly bare ice appearing in large numbers.

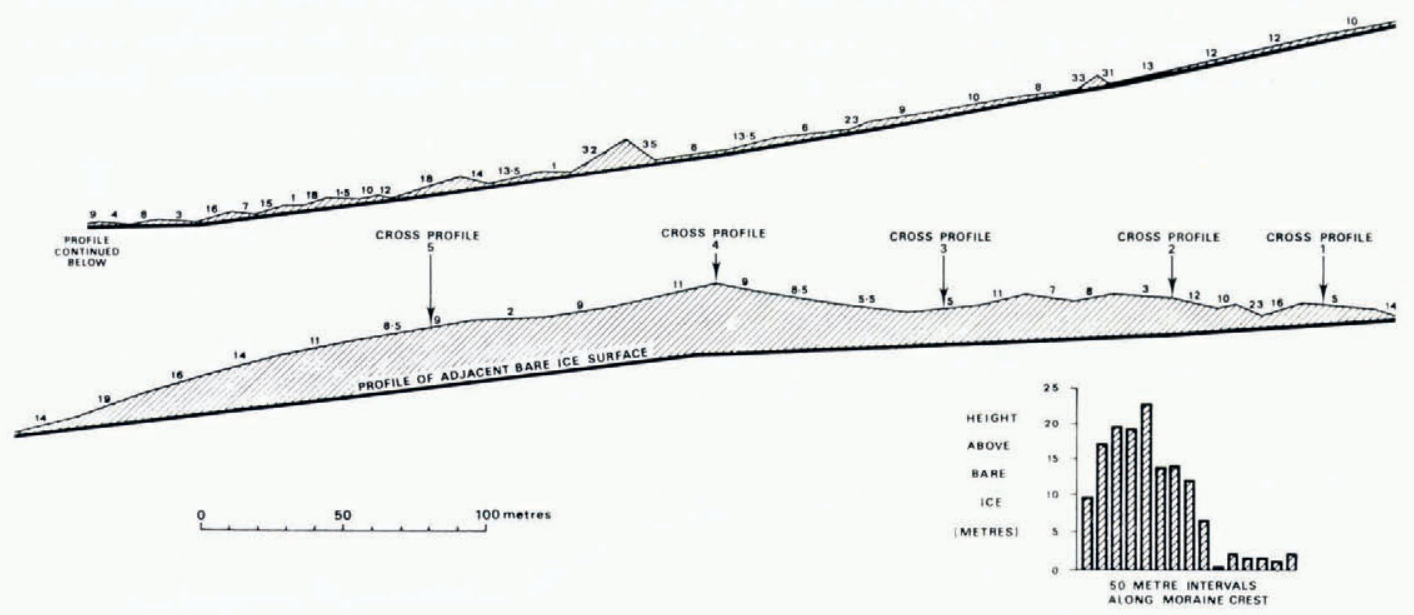

Fig. 2. Long-profile of the main medial moraine of the Glacier de Tsidjiore Nouve, September 1971.

\section{B. Factors in the development of the Medial MORAines}

It is postulated that the emergence of the medial moraines as surface accumulations results from ice ablation that is cumulatively greater in a down-glacier direction; indeed no other explanation seems feasible. The subsequent development of the moraines as morphological features must largely be the product of differential ablation of bare and protected ice. Measurements at four sites on the Glacier de Tsidjiore Nouve made in I97 I and derived from bamboo canes inserted into holes drilled into the ice surface showed that ablation beneath a $6 \mathrm{~cm}$ debris layer amounted to only $78.3 \%$ of that of nearby clean ice. This figure accords with the $66 \%$ determined for Isfallsglaciären by Østrem (1959, I965) and the $74 \%$ derived by Loomis (1970) for the Kaskawulsh Glacier, Alaska. The results of a more recent and detailed study of the Glacier de Tsidjiore Nouve, involving measurements of ablation at eleven sites forming a transect of the glacier, are shown in Table I. From this it will be seen

Table I. Ablation transect September 1972

\begin{tabular}{clcr} 
Site No. & \multicolumn{1}{c}{$\begin{array}{c}\text { Description } \\
\text { Mean diurnal } \\
\text { ablation } \\
\mathrm{cm}\end{array}$} & $\begin{array}{c}\text { \% of mean diurnal } \\
\text { ablation of bare ice }\end{array}$ \\
1. & Bare white ice & 1.97 & - \\
2. & I cm fine debris & 3.69 & 172.3 \\
3. & $2-3 \mathrm{~cm}$ coarse debris & 1.69 & 78.9 \\
4. & I cm fine debris & 2.61 & - \\
5. & Bare dark ice & 1.92 & - \\
6. & Bare white ice & 2.52 & 85.0 \\
7. & $3-4 \mathrm{~cm}$ coarse debris & 1.82 & 62.6 \\
8. & $7 \mathrm{~cm}$ coarse and fine debris & 1.34 & 66.3 \\
9. & $2 \mathrm{~cm}$ coarse debris & 1.42 & 64.1 \\
10. & $3 \mathrm{~cm}$ coarse debris & 1.80 & 63.1 \\
11. & $6 \mathrm{~cm}$ coarse debris & 1.35 & - \\
\hline & Mean ablation: bare ice & $2.14 \mathrm{~cm}$ & 90.6 \\
& Mean ablation: debris covered ice & $1.94 \mathrm{~cm}$ & 73.3
\end{tabular}


that the mean diurnal ablation of covered ice was as high as $90.6 \%$ of that of bare ice. However, the figure has been inflated by the relatively high ablation rates occurring at two sites with a $\mathrm{I} \mathrm{cm}$ cover of debris. If these are abstracted, and the sites with a debris cover of $2 \mathrm{~cm}$ or more are considered, the rate of ablation of protected ice drops to $73 \cdot 3 \%$ of that of bare ice.

These figures clearly support the inference that the development of the Tsidjiore Nouve medial moraines as relief forms is related to differential lowering of the ice-surface over a lengthy period. An hypothesis invoking upthrusting of material along shear-planes (Boulton,

PROFILE 1

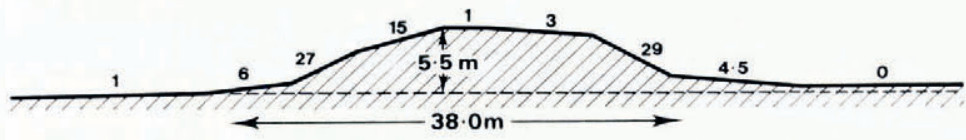

PROFILE 2

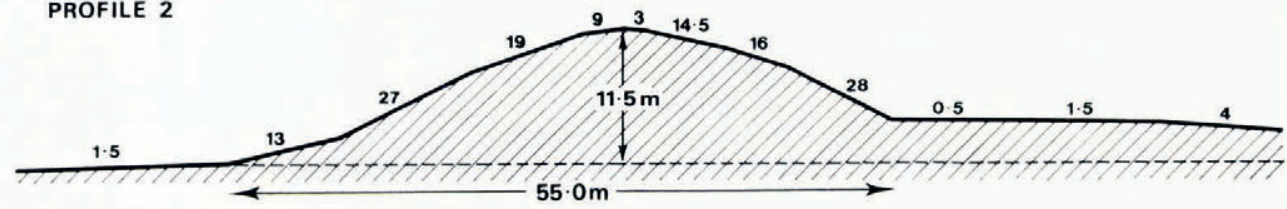

PROFILE 3
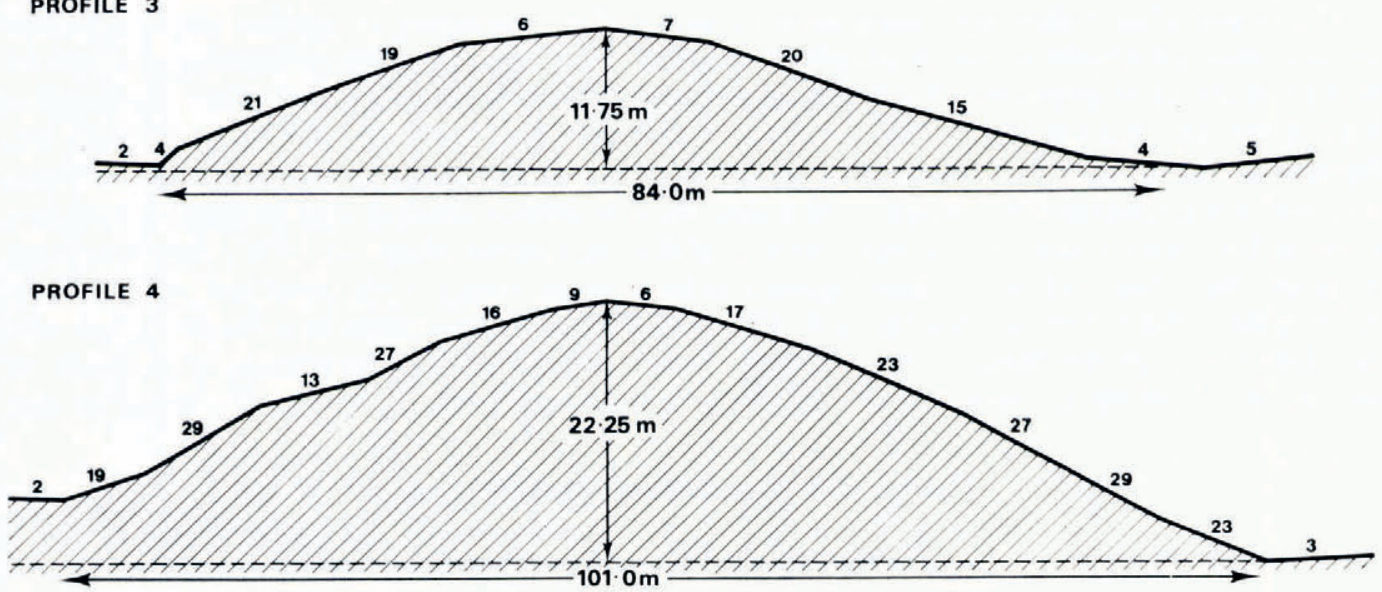

PROFILE 5

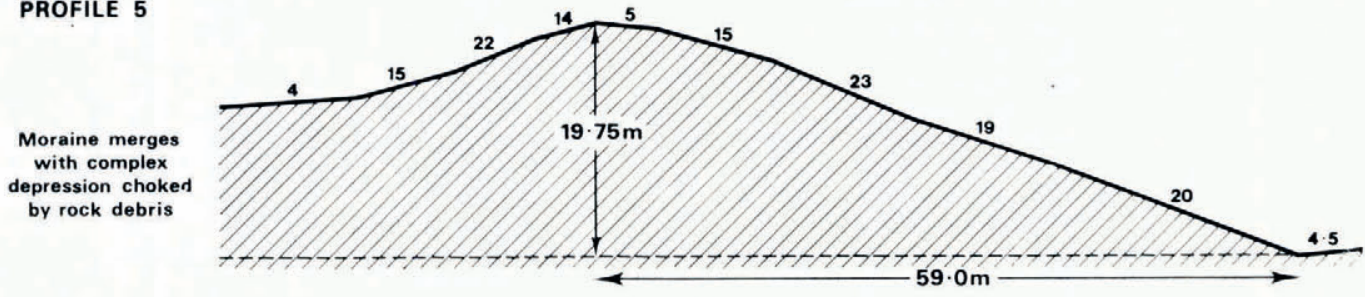

Fig. ${ }_{3}$ A. Cross-profiles of the main medial moraine. 
I 967 , p. 720; Souchez, I966, p. 25I), such as at first sight might be suggested by the irregular nature of the cones and ridges at the heads of the moraines, not only seems unnecessary but is backed by no observable evidence. The postulate already made, that below the Pigne d'Arolla ice fall the rock debris that is to form the moraines is englacial, having been incorporated from above and in some way concentrated in the dark ogives, is adequate to explain all the features noted. Down-glacier this material is exposed in increasing quantities, protecting the subjacent ice and promoting the development of ice-cored mounds and ridges coincident with the dark ice. These will naturally vary in size, depending on the effectiveness of the surface debris in inhibiting ablation. Where a particular season has produced much gelifraction of exposed rock faces, and thus a dark "summer" ice band with a high detrital content, the cover will be thicker and more effective, and a larger-than-average mound will form. An important controlling factor in debris supply may be variations in the configuration of the ice-fall and/or upper glacier from year to year, causing some rock outcrops to be weathered in certain summers but not others. Although these yearly variations will inevitably occur, there will of course be a general tendency for surface detritus to increase down-glacier because of the cumulative effects of ablation. Furthermore this material will eventually be spread, by slipping down the flanks of individual ice cones and ridges, over intervening white ice ogives, to give a continuous longitudinal detrital cover and hence in time a continuous moraine ridge.

One may calculate tentatively the rate at which such medial moraines will grow in height. Assuming the mean annual ablation of bare ice to be $5 \mathrm{~m}$, and that of ice covered by a debris layer $5^{-10} \mathrm{~cm}$ in thickness to be $3.5 \mathrm{~m}$ to $4 \mathrm{~m}$ (figures consistent with ablation rates observed in the field), the annual growth rate will be $\mathrm{I} .0 \mathrm{~m}$ to $\mathrm{I} .5 \mathrm{~m}$. However, ridge growth is not

PROFILE 1

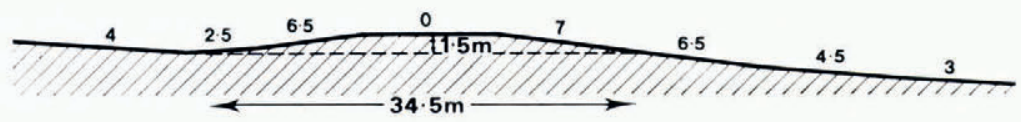

PROFILE 2

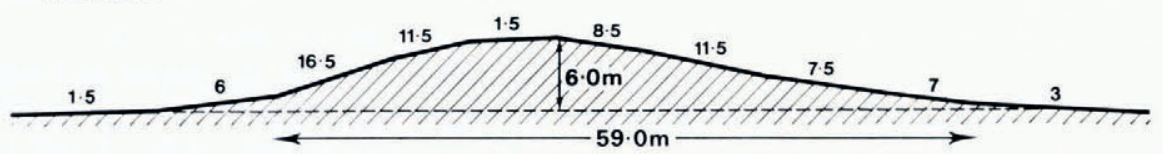

PROFILE 3

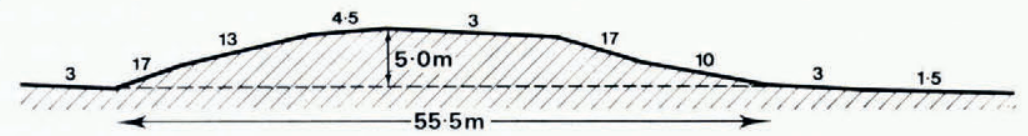

PROFILE 4

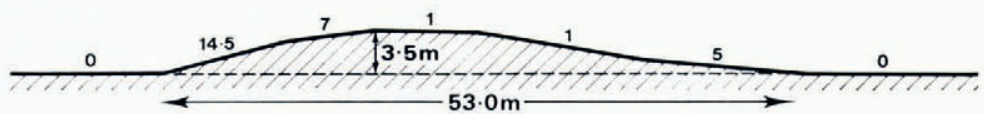

PROFILE 5

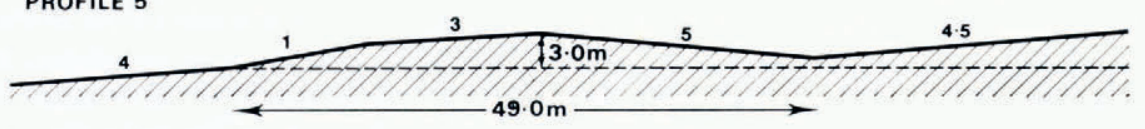

Fig. ${ }_{3} B$. Cross-profiles of the subsidiary medial moraine. 
simply a function of differential melting induced by insolation and atmospheric warmth. As the ridge begins to take shape, it will act as an important longitudinal drainage divide, focusing melt water laterally onto areas of bare ice, which are thus subjected to stream "erosion". In this way the lowering of the bare ice vales is accelerated and the intervening morainic ridges further accentuated. An opposing factor will, however, eventually come into play. As the side slopes of the moraine are steepened, through its growth in height and direct undercutting by marginal melt-water streams, sliding of the debris cover begins. Crosssections of the main moraine (Fig. 3A) indicate that the angles of repose of debris on ice here are as low as $27^{\circ}-29^{\circ}$. If these are exceeded slipping of detritus reveals bare ice, ablation is increased, and the ice slope angle lowered. Once the moraine reaches a critical elevation (in the case of the main moraine evidently $20-25 \mathrm{~m}$ ) the process becomes so important that a further increase of height may be impossible.

\section{Models of moraine development}

Loomis (1970) has proposed the following explanation of the form of the medial moraine of the Kaskawulsh Glacier, Alaska. On the upper part of the glacier the moraine grows in height, relative to adjacent bare ice, owing to the increasing concentration (in a lateral direction) of protective supraglacial rock debris. The maximum height $(20 \mathrm{~m})$ is attained $1.4 \mathrm{~km}$ from the head of the moraine. Subsequently the cover is thinned by lateral sliding over slopes of $39^{\circ}-43^{\circ}$ and by the operation of extending flow. The moraine declines in

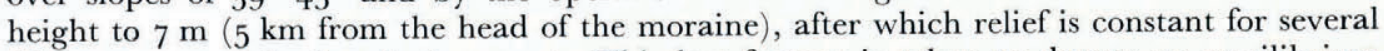
kilometres towards the glacier snout. This last feature is taken to denote an equilibrium condition, with the forces causing the moraine to decline exactly counterbalancing those promoting its vertical growth.

It will be apparent that Loomis' explanation cannot be applied to the moraines of the lower Glacier de Tsidjiore Nouve without some modification. The latter are different not only in scale. A concentration of the upper part of the debris cover, produced on the Kaskawulsh Glacier by lateral compression between two merging ice-streams, does not affect the Tsidjiore Nouve moraines. These remain constant or actually increase in width from the very beginning (note especially the main moraine in Fig. $3 \mathrm{~A}$ ). Moreover, the main moraine of the Glacier de Tsidjiore Nouve, after attaining its maximum vertical dimensions, declines comparatively rapidly down-glacier-indeed within a distance of less than $200 \mathrm{~m}$.

A revised model, incorporating the various suggestions made in this paper and applicable to moraines developing on glaciers fed by major ice falls rather than those resulting from the junction of tributary glaciers (the Kaskawulsh situation), is depicted in Figs. 4 and 5 .

(I) The "waxing" stage. Englacial debris, derived from frost weathering of rock faces immediately adjacent to and/or above the ice surface, is concentrated in relatively narrow zones in the upper layers of the Glacier de Tsidjiore Nouve. As the mode of ingress is assumed to be surface crevasses, the layers charged with debris will not be more than $100 \mathrm{~m}$ in thickness and perhaps less in the case of the subsidiary moraine. One problem encountered in the field is that exposures of ice, on the walls of crevasses and the sides of moulins, rarely show significant concentrations of englacial debris and indeed often appear to be remarkably clean. However, careful examination of the ice surface, particularly in the zone at the head of the moraines, has revealed a considerable number of blocks emerging, usually along the lines of closed crevasses. These blocks are commonly in a state of incipient disintegration, especially where composed of schist, and it it may well be that much of the finer debris comprising the moraines is derived from the breakdown of larger rock fragments either within the ice or when exposed at its surface. An important piece of evidence is afforded by a private investigation carried out by Grande Dixence S.A., Lausanne, in 1951. In an attempt to determine the basal configuration of the Glacier de Tsidjiore Nouve along a line of profile between the base of 


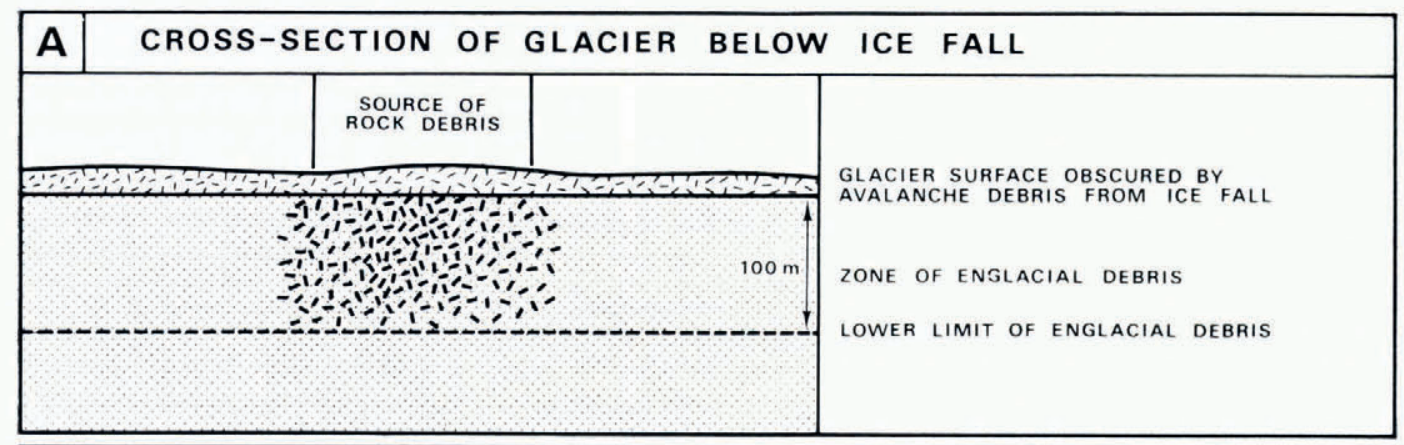

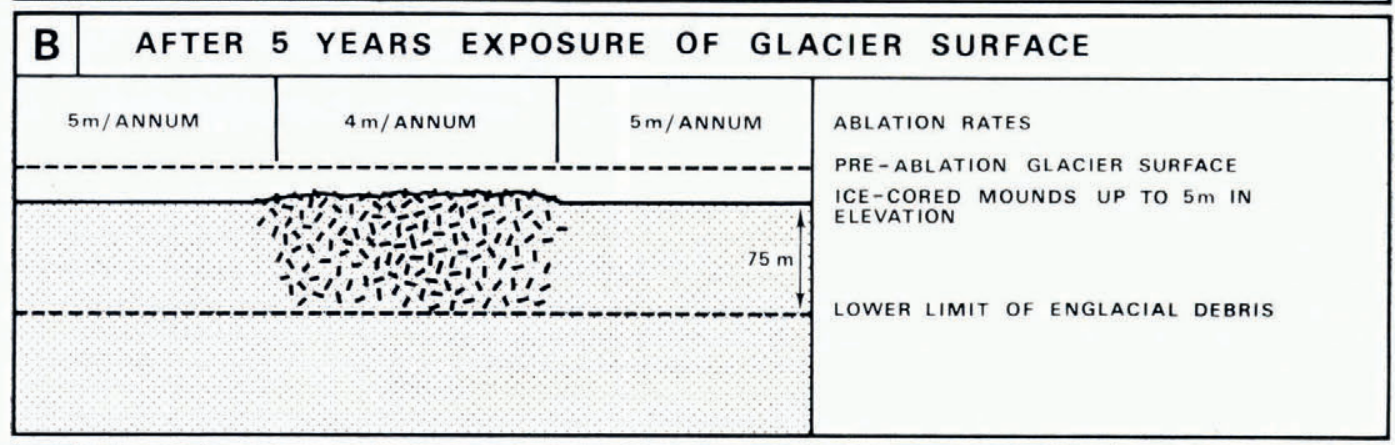

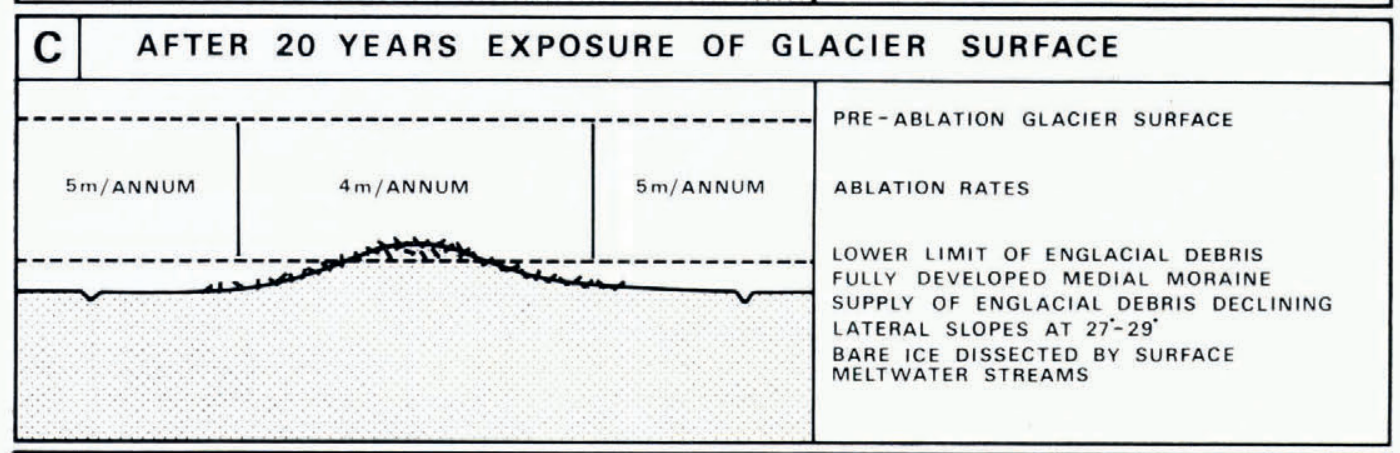

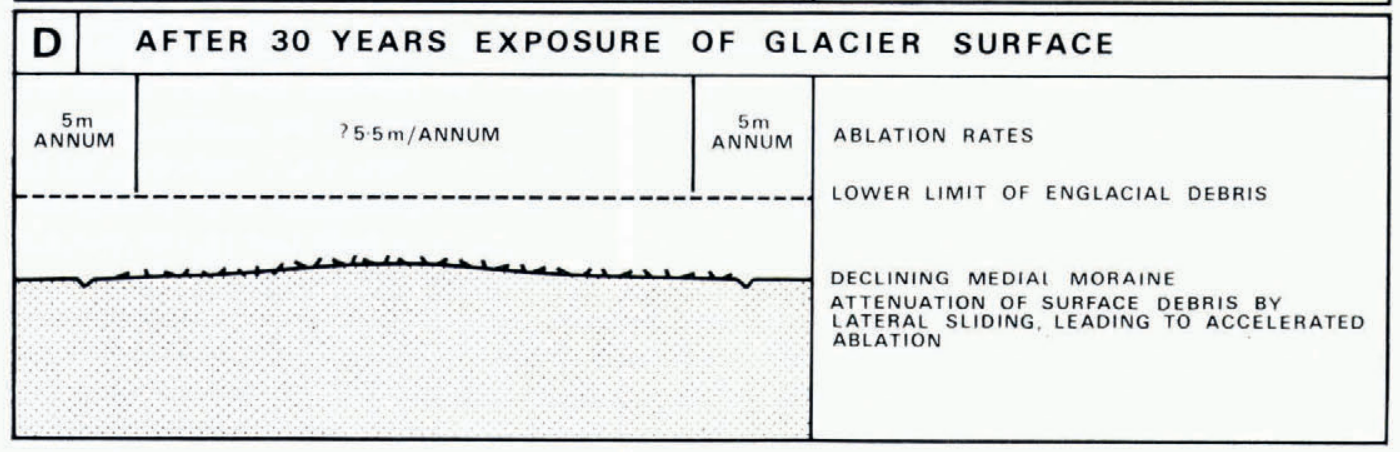

Fig. 4. Model of moraine development: cross-profiles. 
the Pigne d'Arolla ice fall and the points of emergence of the medial moraines, 40 electrothermal probes were inserted into the ice. Of these, 22 reached the base of the glacier, showing this to be generally at a depth of $160-183 \mathrm{~m}$; 18 on the other hand failed because the probes were impeded by englacial rocks-and of these $50 \%$ were terminated at depths between 48 and $95 \mathrm{~m}$ and none at a depth greater than i $10 \mathrm{~m}$. To return to the model, as such englacial material is released by ablation the moraines grow in height and continuity down-glacier (Figs. $4 \mathrm{~A}, \mathrm{~B}, \mathrm{C}$ and ${ }_{5} \mathrm{~A}$ ). However, at a stage prior to the release of all englacial debris, surface concentration may be reduced by sliding over lateral slopes as these approach $30^{\circ}$.
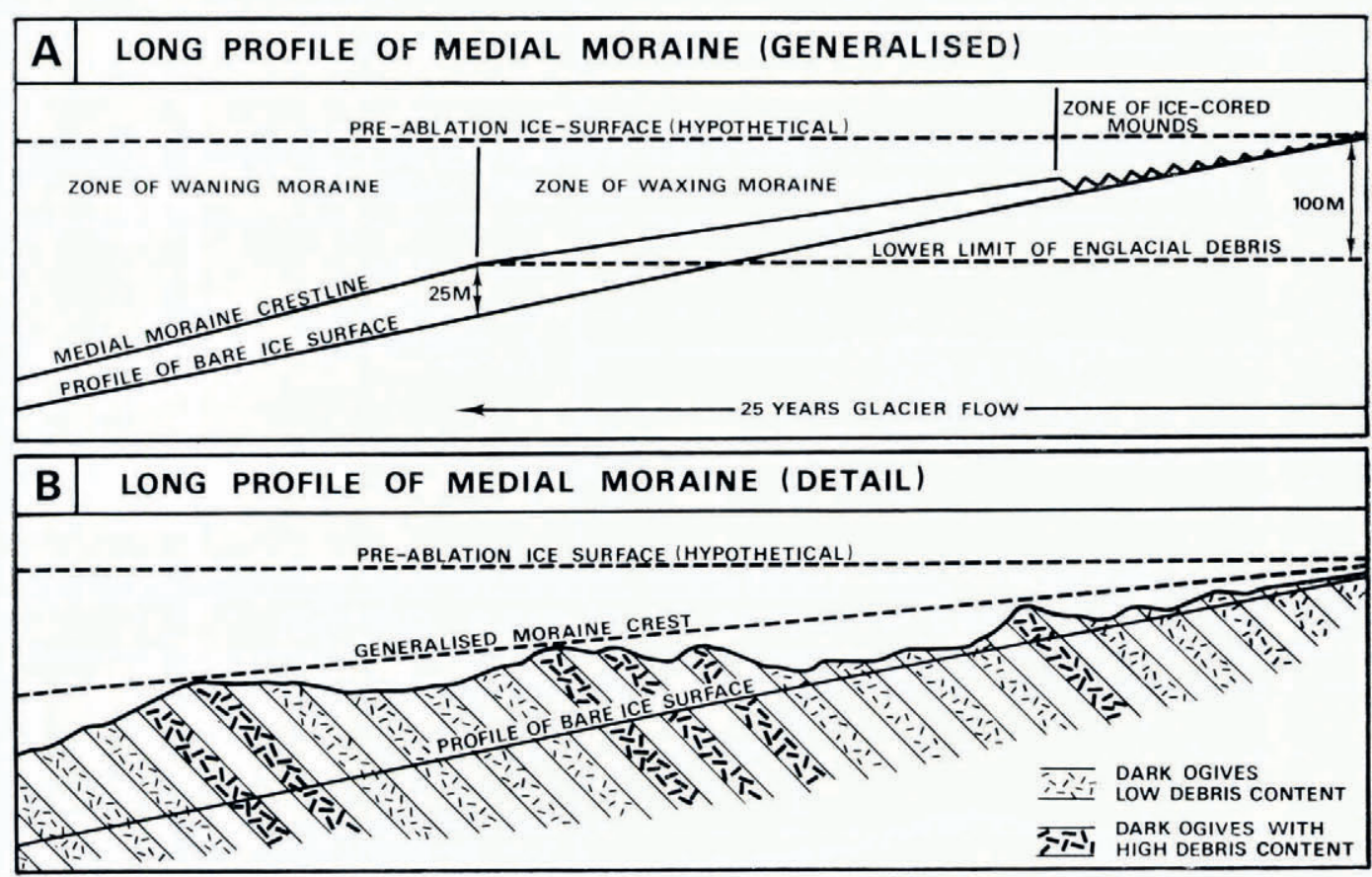

Fig. 5. Model of moraine development: long-profiles.

(2) The "waning" stage. After attaining maximum relief the moraines decline owing to the operation of several factors (Figs. ${ }_{4} \mathrm{D}$ and $5 \mathrm{~A}$ ). Most important is attenuation of the protective cover as the supply of englacial debris falls away and lateral spreading of a constant amount of surficial moraine continues. However, it needs to be realized that this would not cause a significant reduction in the height of the moraine, or even permit the attainment of the equilibrium state envisaged by Loomis, unless thinning of the moraine cover caused an initial increase in the rate of ablation above that of bare ice; hence the assumption of an accelerated rate of $5.5 \mathrm{~m}$ per annum in Figure ${ }_{4} \mathrm{D}$. That this may be justified is indicated by the observations of Østrem (who found that with a cover of less than $0.5 \mathrm{~cm}$ the ablation rate was raised to approximately $130 \%$ of that of bare ice) and Loomis (who produced a comparable figure of $129 \%$ ). Measurements made in September 1972 along the crest of the main Tsidjiore Nouve moraine in its waning section offer further support (Table II). The debris cover here was found to decline down the moraine from a continuous $4 \mathrm{~cm}$ layer (surmounted by numerous stones and boulders) to a patchy layer revealing an increasing amount of bare ice. In the same direction ablation increased from $45.3 \%$ (site IA) to $125.7 \%$ (site $4 \mathrm{~A}$ ) of the rate for bare ice. 
Table II. Ablation on the main moraine September i 972

$\begin{array}{clcc}\text { Site } N o . & \begin{array}{c}\text { Mean diurnal } \\ \text { ablation } \\ \mathrm{cm}\end{array} & \begin{array}{c}\% \text { of mean diurnal } \\ \text { ablation of bare ice }\end{array} \\ \text { IA } & \text { 4 cm debris } & 0.97 & 45 \cdot 3 \\ \text { 2A } & 2-3 \mathrm{~cm} \text { debris } & 1.72 & 80.3 \\ \text { 3A } & \text { Patches of debris } 2-3 \mathrm{~cm} & 2.5 \mathrm{I} & 1 \mathrm{I} 7.3 \\ \text { 4A } & \text { Bare ice between dispersed debris patches } & 2.69 & 125 \cdot 7\end{array}$

The model proposed is sufficiently flexible to allow form complexities and contrasts between individual moraines to be accommodated. Thus the subsidiary moraine of the Tsidjiore Nouve glacier failed to reach the height of the main moraine because the initial supply of debris was much smaller (this is manifestly obvious in the field). Possibly too the supply ran out sooner because the englacial material occupied a thinner layer of ice. For both reasons the subsidiary moraine "peaks" some $200 \mathrm{~m}$ further up-glacier than the main moraine. Furthermore its subsequent slow decline is related to the lack of lateral sliding, for owing to its restricted elevation the marginal slopes rarely exceed $15^{\circ}$ and are usually much less (Fig. $3_{3}$ ). Finally, detailed variations of height (associated, for example, with the individual ice mounds and secondary peaks of the main moraine) are probably related to differential rates of incorporation of frost-weathered material (Fig. $5 \mathrm{~B}$ ). Indeed such an inference is essential if reversed (i.e. up-glacier) slopes along the crest of the moraine are to be satisfactorily explained.

MS. received 28 September 1972 and in final form 5 September 1973

\section{REFERENCES}

Boulton, G. S. 1967. The development of a complex supraglacial moraine at the margin of Sørbreen, Ny Friesland, Vestspitsbergen. Fournal of Glaciology, Vol. 6, No. 47, p. 71 7-35.

Embleton, C., and King, C. A. M. 1968. Glacial and periglacial geomorphology. London, Edward Arnold (Publishers) Ltd.

King, C. A. M., and Lewis, W. V. 1961. A tentative theory of ogive formation. Fournal of Glaciology, Vol. 3, No. 29, p. $9^{1} 3-39$.

Loomis, S. R. 1970. Morphology and ablation processes on glacier ice. (In Bus'.tnell, V. C., and Ragle, R. H., ed. Icefield Ranges Research Project. Scientific results. Vol. 2. New York, American Geographical Society; Montreal, Arctic Institute of North America, p. 27-31.)

Ostrem, G. 1959. Ice melting under a thin layer of moraine and the existence of ice cores in moraine ridges. Geografiska Annaler, Vol. 41, No. 4, p. 228-30.

Ostrem, G. 1965. Problems of dating ice-cored moraines. Geografiska Annaler, Vol. 47A, No. 1, p. I-38.

Souchez, R. A. 1966. The origin of morainic deposits and the characteristics of glacial erosion in the western Sor-Rondane, Antarctica. Fournal of Glaciology, Vol. 6, No. 44, p. 249-54. 